\title{
Trends of road dust emissions contributions on ambient air particulate levels at rural, urban and industrial sites in southern Spain
}

\author{
F. Amato ${ }^{1}$, A. Alastuey ${ }^{1}$, J. de la Rosa ${ }^{2}$, Y. Gonzalez Castanedo ${ }^{2}$, A. M. Sánchez de la Campa ${ }^{2}$, M. Pandolfi ${ }^{1}$, \\ A. Lozano ${ }^{3}$, J. Contreras González ${ }^{4}$, and X. Querol ${ }^{1}$ \\ ${ }^{1}$ Institute of Environmental Assessment and Water Research (IDÆA), Spanish Research Council (CSIC), C/Jordi Girona \\ 18-26, 08034 Barcelona, Spain \\ ${ }^{2}$ Associate Unit CSIC-University of Huelva "Atmospheric Pollution", Center for Research in Sustainable Chemistry \\ (CIQSO), University of Huelva, E21071 Huelva, Spain \\ ${ }^{3}$ Agencia de Medio Ambiente y Agua de Andalucía- Consejería de Agricultura, Pesca y Medio Ambiente, Junta de \\ Andalucía, C/Johan G. Gutenberg 1, Isla de la Cartuja, 41092 Seville, Spain \\ ${ }^{4}$ Consejería de Agricultura, Pesca y Medio Ambiente, Avda. Manuel Siurot 50, 41071 Seville, Spain \\ Correspondence to: F. Amato (fulvio.amato@idaea.csic.es)
}

Received: 4 September 2013 - Published in Atmos. Chem. Phys. Discuss.: 6 December 2013

Revised: 14 February 2014 - Accepted: 21 February 2014 - Published: 8 April 2014

\begin{abstract}
The impact of road dust emissions on $\mathrm{PM}_{10}$ and $\mathrm{PM}_{2.5}$ (atmospheric particulate matter with diameteer $<10 \mu \mathrm{m}$ and $2.5 \mu \mathrm{m}$ mass concentrations recorded from 2003 to 2010 at 11 locations (rural, urban and industrial) in southern Spain was estimated based on the chemical characterization of PM and the use of a constrained Positive Matrix Factorization, where the chemical profile of local road dust samples is used as a priori knowledge. Results indicate that road dust increased $\mathrm{PM}_{10}$ levels on average by $21-35 \%$ at traffic sites, 29-34\% at urban background sites heavily affected by road traffic emissions, $17-22 \%$ at urban-industrial sites and 9-22\% at rural sites. Road dust contributions to ambient PM levels show a marked seasonality with maxima in summer and minima in winter, likely due to the rainfall frequency. Decreasing concentration trends over the sampling years were found at some traffic and urban sites but in most cases the decreases were less significant than for vehicle exhaust emissions, while concentrations increased at industrial sites, probably due to local peculiarities. Concerning $\mathrm{PM}_{2.5}$, road dust contributions were lower than in $\mathrm{PM}_{10}$, as expected but still important $(21-31 \%, 11-31 \%, 6-16 \%$ and $7 \%$ for traffic, urban background, urban-industrial and rural sites, respectively). In addition the three main sources of road dust (carbonaceous particles, brake wear and road wear/mineral)
\end{abstract}

were identified and their contributions to road dust mass loadings estimated, supporting the idea that air quality managers should drive measures aimed at preventing the build-up of road dust particles on roads.

\section{Introduction}

$\mathrm{PM}_{10}$ concentrations in large European cities have not been decreasing as expected over the last decade (EEA, 2012; Harrison et al., 2008). This might be due to the underestimation (or absence) of important sources of primary PM in emission inventories (e.g., road dust) or to secondary aerosol precursors whose emission reductions have not been substantial (e.g., $\mathrm{NO}_{\mathrm{x}}$, VOC and $\mathrm{NH}_{3}$ ). Kousoulidou et al. (2008) showed clear evidence that non-exhaust sources (road dust and wear emissions) become increasingly important as no emission control strategies are taken by member states. Road dust emissions are also identified as the source responsible for the mismatch between modeled and observed $\mathrm{PM}_{10}$ concentrations in cities (Schaap et al., 2009, among others).

The most evident impact of road dust emissions is the contribution to PM mass (parameter regulated by the EU Directive 2008/50/EC), due to their relatively coarse size 
distribution (typically between 1 and $10 \mu \mathrm{m}$ ), causing a high number of the exceedances of air quality limit values at urban and traffic sites. However, road dust is also of concern due to the high content of specific harmful components such as heavy metals and metalloids (i.e., $\mathrm{Cu}, \mathrm{Sb}, \mathrm{Sn}, \mathrm{Fe}, \mathrm{Zn}, \mathrm{Mo}$; Amato et al., 2009a), sulphides and carbonaceous aerosols such as elemental and organic carbon (EC and OC) and Polycyclic Aromatic Hydrocarbons (PAHs; Pengchai et al., 2004; Majumdar et al., 2012) among others. Heavy metals and sulphides originate from the erosion of brake and tire materials and induce oxidative stress (Yanosky et al., 2012). In California, a correlation between atmospheric concentrations of heavy metals $(\mathrm{Fe}, \mathrm{Cu}, \mathrm{Zn}$ and $\mathrm{Ni}$ ) and the mortality rate due to ischemic heart disease was recently found (Cahill et al., 2011). In Stockholm, Meister et al. (2012) estimated a $1.7 \%$ increase in daily mortality per $10 \mu \mathrm{g} \mathrm{m}^{-3}$ increase in $\mathrm{PM}_{2.5-10}$ concentrations that include road dust and other coarse-size particles. The association with $\mathrm{PM}_{2.5-10}$ was stronger for the November-May period when road dust was found to be highest due to the pavement wear due to studded tires. Exposure to an increase equivalent to the interquartile range of road dust contributions (below $2.5 \mathrm{mi}-$ crons) was associated with a $7 \%$ increment of cardiovascular mortality in Barcelona (Ostro et al., 2011). Gustafsson et al. (2008) found that particles from road wear caused by studded tires are at least as inflammatory as particles from diesel exhaust.

Given this evidence, the actual pollution scenario is not encouraging. An overview of atmospheric concentrations of heavy metals in Spain (more than 20 monitoring sites) revealed that the highest concentrations of $\mathrm{Fe}, \mathrm{Cu}, \mathrm{Sr}, \mathrm{Sb}, \mathrm{Ti}$ and $\mathrm{Ba}$ (and partly also $\mathrm{Zn}$ and $\mathrm{Zr}$ ) are measured inside cities (rather than at industrial hotspots), where most of the population live and work (Querol et al., 2007). Concentrations increase further at roadside locations, to which a significant part of the population is also exposed. Consequently, for these metals, population exposure is much higher than for common industrial tracers such as As and Cd. Investigating the role of non-exhaust emissions in air quality impairment and their impact on health is therefore a non-regret policy and a must for local authorities, considering that such particles are mostly emitted locally and are therefore easier to control/mitigate, because it would improve public health.

The identification of individual source contributions is crucial for the understanding of health effects since lowcontributing sources may be more relevant for health. Differentiating the contribution of road dust from other traffic sources is however problematic: the complexity of the urban environment does not always allow for a clear separation of road traffic sources; consequently, most of the source apportionment studies presented so far show results only for total contributions from road traffic emissions (Viana et al., 2008). It is also common to find studies where the road dust component of traffic emissions is mixed with other mineral/soil sources. PM contributions from vehicular traf- fic should be differentiated, distinguishing between exhaust and non-exhaust fraction. Ideally non-exhaust contributions should be further separated into road dust, brake, tire and road wear.

The relative importance of these categories changes greatly, depending on space and on time. Spatially, road dust emissions increase largely in southern Europe (due to a drier climate) and Scandinavian countries (due to road sanding and the use of studded tires) (Querol et al., 2004) but also within a city environment, e.g., next to construction sites and on heavy traffic roads (Amato et al., 2009a). With regard to time, road dust emissions are severely influenced by meteorology (precipitation, insulation, road humidity and droughts; Amato et al., 2012). In addition, it is important to monitor the relative increase of non-exhaust emissions (currently uncontrolled) against the motor exhaust emissions, which have been progressively reduced in the last two decades by means of the Euro (1 to 6) standards.

To date, research on non-exhaust emissions has been rather limited due to the difficulties encountered by experimentalists and modelers in characterizing and describing the complex phenomenon of road dust resuspension and wear emissions.

In this study we aim to contribute to the improvement in current knowledge on road dust emissions by estimating their impact on $\mathrm{PM}_{10}$ and $\mathrm{PM}_{2.5}$ levels measured at 11 receptors distributed at traffic, urban, industrial and rural location across Andalusia, the most arid and populated region of Spain, which also suffers from frequent Saharan dust deposition events.

\section{Methods}

\subsection{Study area}

Andalusia is the most populated region in Spain with eight provinces and 8.4 million inhabitants. The local economy is basically based on tourism, being the primary (agriculture, fishing and mining) and industrial sectors only a small percentage of the gross value added. Urban road traffic is very dense due to the often insufficient public transport infrastructure (metro, tram, buses) and to the high density of urban architecture. Climate is typically Mediterranean, with dry and hot summers and mild winters, favoring the build-up and mobilization of road dust particles and their entrainment into the atmosphere due to the wheel- and vehicle-induced turbulence.

Due to the evident impact of road dust emissions and their increasing relevance (Harrison et al., 2008; Denier van der Gon et al., 2013) to urban air quality the Regional Government of Andalusia has recently promoted research studies aimed at evaluating the impact of road dust emissions on air quality measured in large cities and industrial areas of Andalusia. The five cities under study (Seville, Málaga, 


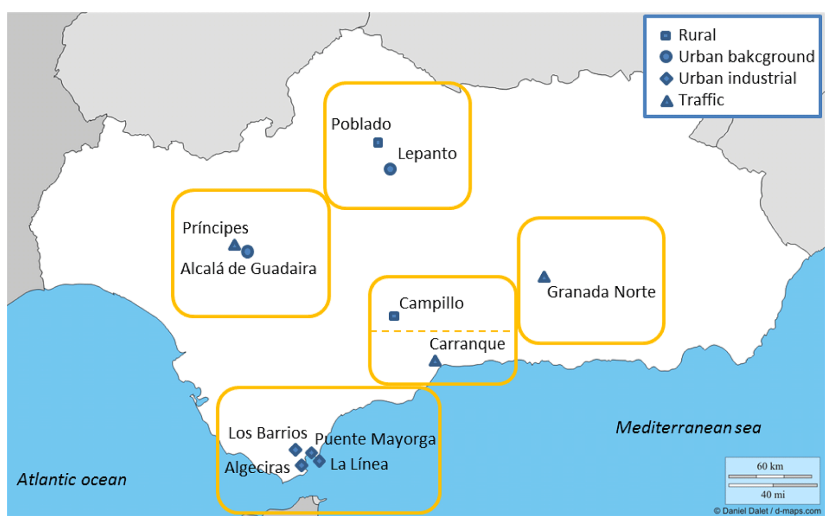

Fig. 1. Map of the 11 monitoring sites (divided into six zones) used for the PM source apportionment study.

Córdoba, Granada and Algeciras Bay; Fig. 1) are briefly described below:

- Seville, the capital of Andalusia, is the fourth largest city of Spain, counting 700000 inhabitants, and 1.5 million in the metropolitan region. The city is built on the flat depression of Guadalquivir River and hosts the only inland port of Spain. Road traffic emissions have been partially reduced by the recent construction of tram and underground lines.

- Málaga is the second most populous city of Andalusia, with a population of 600000 (metropolitan area). It lies on the Mediterranean coast, $100 \mathrm{~km}$ east of the Strait of Gibraltar, and it is bordered to the north by a high mountain range. Málaga is a city of commerce and tourism; therefore, the local anthropogenic pollutant source is mainly traffic.

- Córdoba (330000 inhabitants) is one of the main tourist destinations in Spain. The city is located on the banks of the Guadalquivir River and has the highest summer average daily temperature in Europe $\left(36.2^{\circ}\right.$ in July). The climate is Mediterranean-continental. Precipitation is concentrated in autumn-winter and summer is often characterized by droughts.

- Granada (738 ma.s.1.) is a non-industrialized and medium-sized city with 250000 inhabitants. The city is located in a natural valley surrounded by mountains with elevations between 1000 and $3350 \mathrm{~m}$ a.s.l. Traffic is the most important source of anthropogenic pollutants in Granada. The topography of Granada favors the development of thermal inversions in winter, with a significant accumulation of pollutants in the study area (Lyamani et al., 2008).

- Algeciras Bay hosts the largest port of Spain (70 million tonnes), oil refinery and stainless steel plants. It is around $10 \mathrm{~km}$ long by $8 \mathrm{~km}$ wide. To the south, it opens into the Strait of Gibraltar, where around 80000 ships per year leave the Mediterranean and pass into the Atlantic. Due to all these activities along the shoreline, air pollution is a severe problem in the area. Heavy trucks visibly dominate road transport. This area is also characterized by a high population density, with more than 300000 inhabitants.

\subsection{Ambient air PM sampling}

$\mathrm{PM}_{10}$ and $\mathrm{PM}_{2.5}$ samples were collected at the five provinces under study from 2003 to 2010. Details of most of the monitoring stations considered in this work can be found in de la Rosa et al. (2010). Sampling periods and frequency varied among sites; details are shown in Table 1. Eleven stations were selected from among rural, urban background, traffic and urban-industrial environments:

- in Seville province, one traffic (Príncipes) and one urban background site (Alcalá de Guadaira), the latter being located in the suburbs of the city, were used. Several studies on air quality have already been performed in metropolitan area of Seville (Adame et al., 2012; Notario et al., 2012).

- in Málaga province, one traffic (Carranque) and one rural site (Campillo), located $60 \mathrm{~km}$ northwest of the city, were chosen. The optimization of air quality monitoring networks for nitrogen dioxide and ozone has been performed in Málaga (see details in Lozano et al., 2009).

- in the province of Córdoba, one urban background (Lepanto) and one rural site (Poblado) were selected. (García Lorenzo, 2011). Details of the monitoring stations can be found in Lozano et al. (2009).

- in the city of Granada, the traffic monitoring site Granada Norte was used, located in between the two carriageways of the Davalos avenue, used by a total of 15000 vehicles per day.

- in Algeciras Bay four urban-industrial monitoring sites were used (Los Barrios, La Línea, Algeciras and Puente Mayorga). Details can be found in Pandolfi et al. (2011) and Gonzalez Castanedo (2011).

Daily PM samples were collected by means of high volume Andersen $\left(68 \mathrm{~m}^{3} \mathrm{~h}^{-1}\right.$ onto rectangular filters $)$ and MCV $\left(30 \mathrm{~m}^{3} \mathrm{~h}^{-1}\right.$ onto circular filters) samplers with a frequency of 1-2 samples per week at all sites. A total of 2696 filters were collected on quartz fiber filters (Schleicher \& Schuell, Munktell and Pallflex). Before sampling, quartz fiber filters were dried at $205^{\circ} \mathrm{C}$ for $4 \mathrm{~h}$ and conditioned for $48 \mathrm{~h}$ at $20^{\circ} \mathrm{C}$ and $50 \%$ of relative humidity. Weights of blank filters were measured three times every $24 \mathrm{~h}$ (or five times in the case of rectangular filters) using a Sartorius LA 130 S-F microbalance 
Table 1. Details of PM monitoring sites and sampling periods.

\begin{tabular}{|c|c|c|c|c|c|c|c|}
\hline $\begin{array}{l}\text { Monitoring } \\
\text { site }\end{array}$ & Province & $\begin{array}{l}\text { Type of } \\
\text { station }\end{array}$ & Latitude & Longitude & $\begin{array}{l}\text { Altitude } \\
\text { (m a.s.l.) }\end{array}$ & Period & $\begin{array}{r}\text { Number of } \\
\text { filters }\end{array}$ \\
\hline Campillo & Málaga & Rural & $37^{\circ} 2^{\prime} 43.27^{\prime \prime} \mathrm{N}$ & $4^{\circ} 51^{\prime} 41.23^{\prime \prime} \mathrm{W}$ & & $\begin{array}{l}\mathrm{PM}_{10}(2010) \\
\mathrm{PM}_{2.5}(2009)\end{array}$ & 95 \\
\hline Poblado & Córdoba & Rural & $38^{\circ} 6^{\prime} 36^{\prime \prime} \mathrm{N}$ & $4^{\circ} 55^{\prime} 36^{\prime \prime} \mathrm{W}$ & & $\mathrm{PM}_{10}(2010)$ & 21 \\
\hline Lepanto & Córdoba & Urban & $37^{\circ} 53^{\prime} 39.1^{\prime \prime} \mathrm{N}$ & $4^{\circ} 46^{\prime} 5.5^{\prime \prime} \mathrm{W}$ & 123 & $\begin{array}{l}\mathrm{PM}_{10}(2007-2010) \\
\mathrm{PM}_{2.5}(2009-2010)\end{array}$ & 225 \\
\hline Alcalá de Guadaira & Seville & Urban & $37^{\circ} 20^{\prime} 31.4^{\prime \prime} \mathrm{N}$ & $5^{\circ} 49^{\prime} 59.7^{\prime \prime} \mathrm{W}$ & 60 & $\begin{array}{l}\mathrm{PM}_{10}(2007-2010) \\
\mathrm{PM}_{2.5}(2009)\end{array}$ & 196 \\
\hline Granada Norte & Granada & Traffic & $37^{\circ} 11^{\prime} 50.8^{\prime} \mathrm{N}$ & $3^{\circ} 36^{\prime} 28^{\prime} \mathrm{W}$ & 689 & $\begin{array}{l}\mathrm{PM}_{10}(2007-2010) \\
\mathrm{PM}_{2.5}(2009-2010)\end{array}$ & 217 \\
\hline Carranque & Málaga & Traffic & $36^{\circ} 43^{\prime} 12.8^{\prime \prime} \mathrm{N}$ & $4^{\circ} 25^{\prime} 45.8^{\prime \prime} \mathrm{W}$ & 36 & $\begin{array}{l}\mathrm{PM}_{10}(2007-2010) \\
\mathrm{PM}_{2.5}(2009-2010)\end{array}$ & 222 \\
\hline Príncipes & Seville & Traffic & $37^{\circ} 22^{\prime} 35.6^{\prime \prime} \mathrm{N}$ & $6^{\circ} 0^{\prime} 15.4^{\prime \prime} \mathrm{W}$ & 8 & $\begin{array}{l}\mathrm{PM}_{10}(2007-2010) \\
\mathrm{PM}_{2.5}(2009)\end{array}$ & 214 \\
\hline Algeciras & Cádiz & Urban Industrial & $36^{\circ} 07^{\prime} 50^{\prime \prime} \mathrm{N}$ & $5^{\circ} 26^{\prime} 51^{\prime \prime} \mathrm{W}$ & 20 & $\begin{array}{l}\mathrm{PM}_{10} \text { (Aug 2003-Jul 2004) } \\
\mathrm{PM}_{2.5} \text { (Aug 2003-Jul 2004) }\end{array}$ & 161 \\
\hline La Línea & Cádiz & Urban Industrial & $36^{\circ} 9^{\prime} 34.1^{\prime \prime} \mathrm{N}$ & $5^{\circ} 20^{\prime} 54.39^{\prime \prime} \mathrm{W}$ & 4 & $\begin{array}{l}\mathrm{PM}_{10}(\text { Mar 2003-2010) } \\
\mathrm{PM}_{2.5}(\text { Mar 2003-2010) }\end{array}$ & 632 \\
\hline Los Barrios & Cádiz & Urban Industrial & $36^{\circ} 10^{\prime} 31.6^{\prime \prime} \mathrm{N}$ & $5^{\circ} 28^{\prime} 51.2^{\prime \prime} \mathrm{W}$ & 45 & $\begin{array}{l}\mathrm{PM}_{10} \text { (Feb 2003-2010) } \\
\mathrm{PM}_{2.5} \text { (Feb 2005-2010) }\end{array}$ & 455 \\
\hline Puente Mayorga & Cádiz & Urban Industrial & $36^{\circ} 10^{\prime} 59.7^{\prime \prime} \mathrm{N}$ & $5^{\circ} 23^{\prime} 11.8^{\prime \prime} \mathrm{W}$ & 8 & $\mathrm{PM}_{10}(\mathrm{Sep} 2004-2010)$ & 258 \\
\hline
\end{tabular}

( $1 \mu \mathrm{g}$ sensitivity). After weighing the filters were kept in aluminum foil and brought back to the laboratory to be weighted two more times every $24 \mathrm{~h}$. Once the weights of samples were determined, filters were subjected to several analytical (destructive) treatments. These procedures are briefly listed below; more details are available in Querol et al. (2001):

- half of the filter (or $150 \mathrm{~cm}^{2}$ in the case of rectangular filters) was acid digested $(5 \mathrm{~mL} \mathrm{HF}, 2.5 \mathrm{~mL}$ $\mathrm{HNO}_{3}, 2.5 \mathrm{~mL} \mathrm{HClO}_{4}$ ) for the determination of major and trace elements and analyzed respectively by inductively coupled plasma mass spectrometry and atomic emission spectrometry (ICP-MS and ICP-AES) (Querol et al., 2001).

- a quarter of the filter (or $75 \mathrm{~cm}^{2}$ in the case of rectangular filters) was leached in $20 \mathrm{~mL}$ of bi-distilled water for the extraction of water-soluble ions and subsequent analysis by ion chromatography (IC) for sulfate, nitrate and chloride and by specific electrode for ammonium.

- a section of $1.5 \mathrm{~cm}^{2}$ of the filter was used for the determination of total carbon (TC) by means of a LECO SC-144DR. analyzer. A $1 \%$ TC standard was used as described in the calibration procedure. Previously, sample holders were submitted to a high temperature $\left(1200^{\circ} \mathrm{C}\right)$ in order to eliminate any $\mathrm{C}$ compound. Precision and accuracy was less than $2 \%$ using a TC standard of $1 \%$.

In every case blank concentrations were subtracted for determining final concentrations in the samples.

\subsection{Road dust samplings}

Road dust samples were collected, in each city, at four selected roads in the vicinities of the urban monitoring site used for ambient air PM. Road dust particles were collected on $47 \mathrm{~mm}$ diameter quartz fiber filters (Pallflex) by means of a dry vacuum sampler coupled with a $10 \mu \mathrm{m}$-inlet capable of collecting only the mobile particles with aerodynamic diameter $<10 \mu \mathrm{m}$ from a delimitated area of active road surface. Details of the device and sampling protocol can be found in our previous publication where the mass loadings of road dust were investigated (Amato et al., 2013a). Details of sampling sites are summarized in Table S1 in the Supplement. At each road, three different samples were collected in order to improve representativeness and to collect enough samples for a complete chemical characterization:

- the first filter was acid digested (following the above protocol) to determine the concentration of major ( $\mathrm{Na}$, $\mathrm{Mg}, \mathrm{Al}, \mathrm{Fe}, \mathrm{P}, \mathrm{S}, \mathrm{Cl}, \mathrm{K}, \mathrm{Ca}, \mathrm{Ti}$ and $\mathrm{Mn}$ ) and trace elements (Li, Sc, V, Cr, Co, Ni, Cu, Zn, Ga, Ge, As, Se, $\mathrm{Rb}, \mathrm{Sr}, \mathrm{Zr}, \mathrm{Nb}, \mathrm{Mo}, \mathrm{Cd}, \mathrm{Sn}, \mathrm{Sb}, \mathrm{Cs}, \mathrm{Ba}, \mathrm{La}, \mathrm{Ce}, \mathrm{Hf}$, $\mathrm{W}, \mathrm{Tl}, \mathrm{Pb}, \mathrm{Bi}$, Th and $\mathrm{U}$, among others) by means of ICP-AES and ICP-MS, respectively.

- one half of the second filter was used for a leachate in Milli-Q water $(20 \mathrm{~mL})$ for the extraction of soluble ions and subsequent IC analysis to determine the concentration of sulphate, nitrate, chloride and specific electrode for $\mathrm{NH}_{4}^{+}$.

- a fraction of $1.5 \mathrm{~cm}^{2}$ of the second filter was used for the determination of OC and EC by means of the 


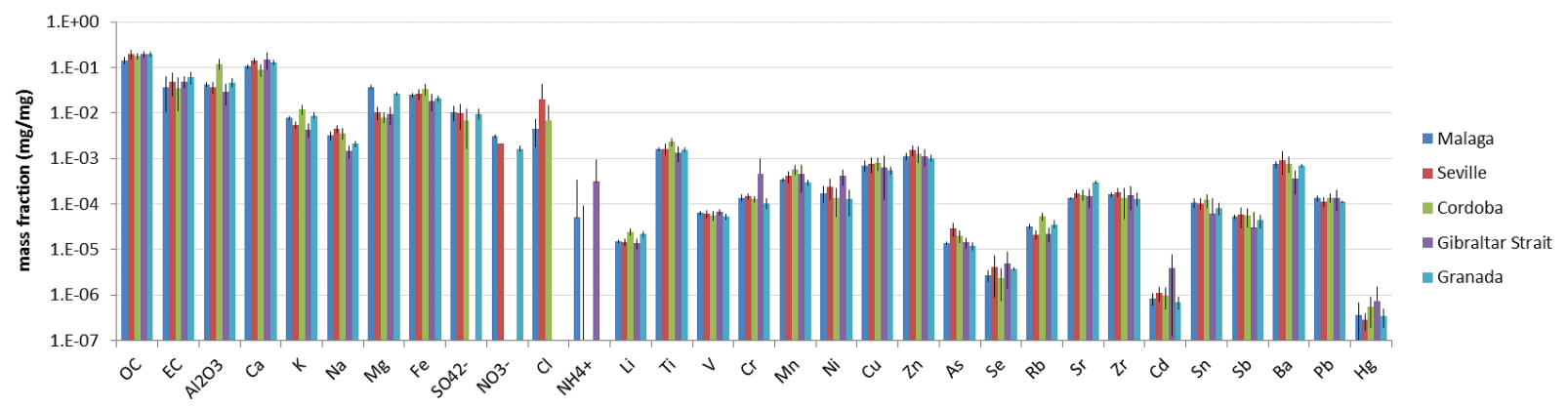

Fig. 2. City-averaged road dust composition at the five cities under study. Error bars indicate standard deviation between four roads.

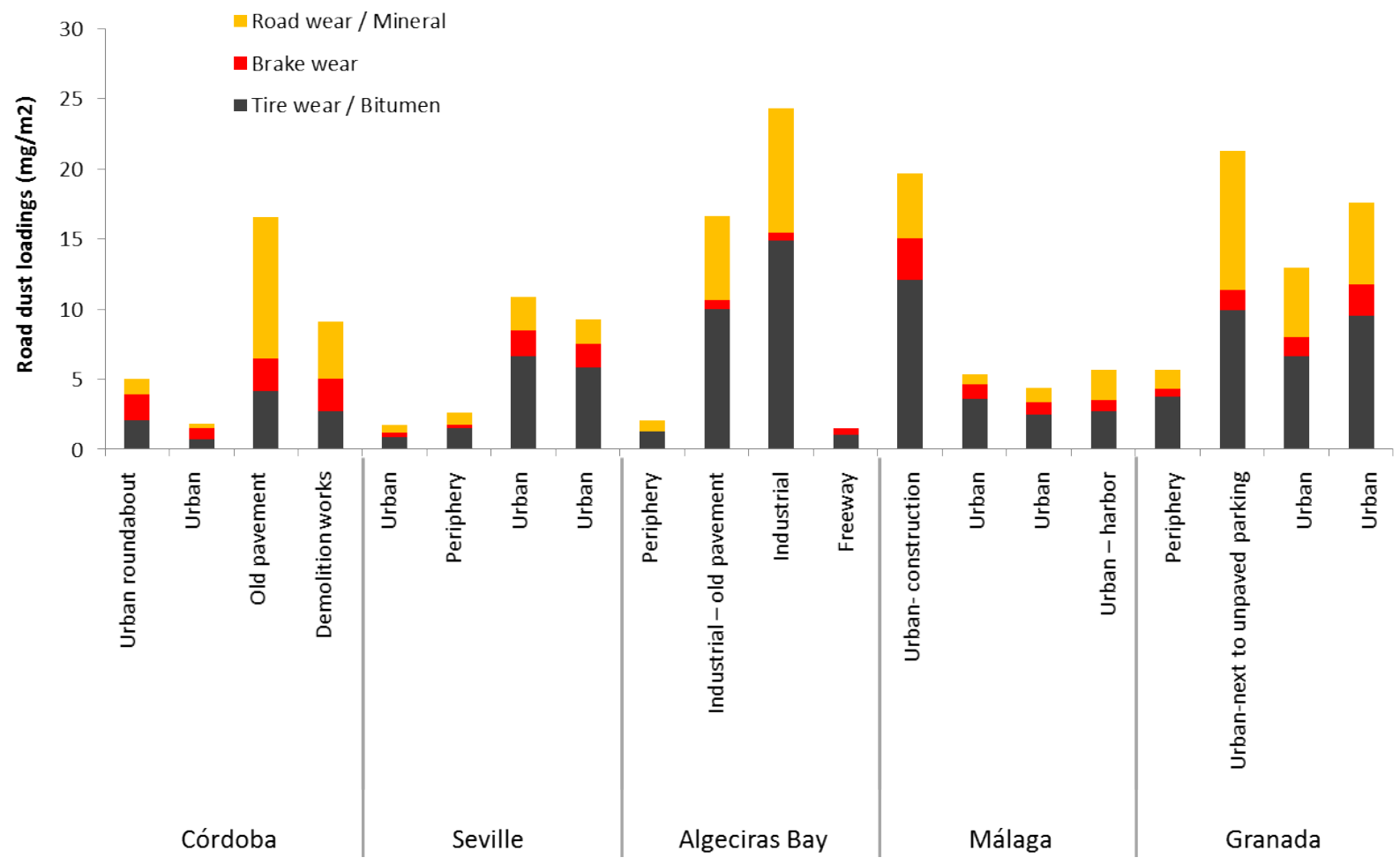

Fig. 3. Absolute contribution $\left(\mathrm{mg} \mathrm{m}^{-2}\right)$ of road dust sources to road dust mass loadings.

Sunset thermal-optical analysis (Birch and Cary, 1996) with the EUSAAR (European Supersites for Atmospheric Aerosol Research) 2 protocol (Cavalli et al., 2010).

- a fraction of $1.5 \mathrm{~cm}^{2}$ of the second filter was used for the determination of particulate $\mathrm{Hg}$ by means of the atomic absorption spectrometer LECO AMA 254.

The third filter was stored for further analysis. For the source apportionment study, the average of the four chemical profiles obtained in each city was used.

\subsection{Source apportionment}

Positive Matrix Factorization (PMF; Paatero and Tapper, 1994) is a widely used model for atmospheric aerosol source apportionment, as well as for other types of samples such as ashes, soils etc. PMF is based on the mass conservation principle:

$x_{i j}=\sum_{k=1}^{p} g_{i k} f_{j k} \quad i=1,2, \ldots, m j=1,2, \ldots, n$,

where $x_{i j}$ is the $i$ th concentration of the species $j, g_{i k}$ is the $i$ th contribution of the source $k$, and $f_{j k}$ is the concentration of the species $j$ in source $k$.

In this study two types of source apportionment analysis were carried out:

- a road dust source apportionment, in order to identify the main sources of road dust and their contribution to observed mass loadings. The road dust source 
apportionment, aimed at identifying the main sources of road dust, was performed by merging the 20 road dust samples obtained in this study with road dust samples from other Spanish cities (Barcelona and Girona; Amato et al., 2011) collected in previous studies by our group in order to improve the statistical basis. Source contribution results are, however, presented only for the sites in Andalusia.

- a PM source apportionment, merging $\mathrm{PM}_{10}$ and $\mathrm{PM}_{2.5}$ data for each area in order to estimate the contribution of the main source of PM, including road dust

In both cases a PMF model was used. For the PM source apportionment a constrained PMF was carried out, divided into six different analyses due to the considerable distance between monitoring sites (a fact which means that the assumption of same sources at all sites may be not valid). The following criteria were considered in order to group the different data sets: (i) distance between monitoring sites; (ii) similarity of PM sources; (iii) number of samples available at each site. The constraints consist of auxiliary equations (added to the main equations by means of the Multilinear Engine 2 programming; Paatero, 1999) in order to:

- pull one factor profile $f_{j k}$ towards the target profile of local road dust, obtained experimentally;

- limit the daily $g_{i k} \mathrm{PM}_{2.5}$ source contribution by the upper $\mathrm{PM}_{10}$ source contribution bound;

- limit the sum of factor profile by the maximum of 1 .

This approach has been already followed by Amato et al. (2009b) and Amato and Hopke (2012), showing a satisfactory theoretical basis. The six analyses were divided as follows:

- $\mathrm{PM}_{10}$ and $\mathrm{PM}_{2.5}$ analyses at Los Barrios, Algecíras and La Línea, and $\mathrm{PM}_{10}$ analysis at Puente Mayorga (four urban-industrial sites of Algecíras Bay). A total of 1506 PM samples were used $\left(298 \mathrm{PM}_{10}\right.$ and $157 \mathrm{PM}_{2.5}$ samples at Los Barrios, $343 \mathrm{PM}_{10}$ and 289 $\mathrm{PM}_{2.5}$ samples at la Línea, $79 \mathrm{PM}_{10}$ and $82 \mathrm{PM}_{2.5}$ samples at Algecíras, $258 \mathrm{PM}_{10}$ samples at Puente Mayorga) against 30 components of PM.

- $\mathrm{PM}_{10}$ and $\mathrm{PM}_{2.5}$ analyses at Poblado (rural) and Lepanto (urban background) stations (Córdoba). A total of $246 \mathrm{PM}$ samples were used $\left(175 \mathrm{PM}_{10}\right.$ and $50 \mathrm{PM}_{2.5}$ samples at Lepanto, $21 \mathrm{PM}_{10}$ samples at Poblado) against 30 components of PM.

- $\mathrm{PM}_{10}$ and $\mathrm{PM}_{2.5}$ analyses at Príncipes (traffic) and Alcalá de Guadaria (urban background) stations (Seville). A total of 410 PM samples were used (170 $\mathrm{PM}_{10}$ and $44 \mathrm{PM}_{2.5}$ samples at Príncipes, $163 \mathrm{PM}_{10}$ and $33 \mathrm{PM}_{2.5}$ samples at Alcalá de Guadaria) against 29 components of PM.
Table 2. Road dust composition averaged per road category.

\begin{tabular}{|c|c|c|c|c|}
\hline & $\begin{array}{l}\text { Urban } \\
\text { roads }\end{array}$ & $\begin{array}{l}\text { Industrial } \\
\text { roads }\end{array}$ & $\begin{array}{l}\text { Nearby } \\
\text { works }\end{array}$ & $\begin{array}{l}\text { Poor state } \\
\text { of pavement }\end{array}$ \\
\hline \multicolumn{5}{|l|}{$\%$} \\
\hline $\mathrm{OC}$ & $19.2 \pm 3.4$ & $15.7 \pm 0.2$ & $17.2 \pm 3.0$ & 12.7 \\
\hline $\mathrm{EC}$ & $5.3 \pm 2.1$ & $3.2 \pm 2.3$ & $4.4 \pm 1.6$ & 2.1 \\
\hline $\mathrm{Al}$ & $2.1 \pm 0.6$ & $2.1 \pm 0.4$ & $3.2 \pm 0.9$ & 4.0 \\
\hline $\mathrm{Ca}$ & $11.2 \pm 3.1$ & $19.7 \pm 1.6$ & $12.7 \pm 1.6$ & 9.9 \\
\hline $\mathrm{Fe}$ & $2.5 \pm 0.5$ & $2.0 \pm 0.6$ & $3.1 \pm 1.4$ & 3.1 \\
\hline $\mathrm{K}$ & $0.7 \pm 0.2$ & $0.5 \pm 0.1$ & $1.1 \pm 0.3$ & 1.5 \\
\hline $\mathrm{Mg}$ & $1.9 \pm 1.3$ & $1.3 \pm 0.3$ & $2.6 \pm 1.5$ & 0.9 \\
\hline $\mathrm{Na}$ & $0.3 \pm 0.1$ & $0.2 \pm 0.1$ & $0.3 \pm 0.1$ & 0.3 \\
\hline $\mathrm{P}$ & $0.1+0.0$ & $0.1 \pm 0.0$ & $0.1 \pm 0.0$ & 0.1 \\
\hline S & $0.4 \pm 0.1$ & $0.3 \pm 0.2$ & $0.4 \pm 0.1$ & 0.2 \\
\hline $\mathrm{Cl}^{-}$ & $0.9 \pm 1.5$ & $0.1+0.0$ & $0.2 \pm 0.3$ & 0.0 \\
\hline $\mathrm{NO}_{3}^{-}$ & $0.2 \pm 0.1$ & $<\mathrm{LD}$ & $0.2 \pm 0.1$ & $<\mathrm{LD}$ \\
\hline $\mathrm{SO}_{4}^{2-}$ & $1.0 \pm 0.4$ & $<\mathrm{LD}$ & $0.9 \pm 0.3$ & 0.3 \\
\hline $\mathrm{NH}_{4}^{+}$ & $<\mathrm{LD}$ & $<\mathrm{LD}$ & $<\mathrm{LD}$ & 0.0 \\
\hline \multicolumn{5}{|l|}{$\mu \mathrm{gg}^{-1}$} \\
\hline $\mathrm{Hg}$ & $0.46 \pm 0.51$ & $0.42 \pm 0.14$ & $0.53 \pm 0.28$ & 0.30 \\
\hline $\mathrm{Li}$ & $17 \pm 4$ & $16 \pm 4$ & $23 \pm 7$ & 26 \\
\hline $\mathrm{Sc}$ & $4 \pm 2$ & $5 \pm 0$ & $6 \pm 2$ & 7 \\
\hline $\mathrm{Ti}$ & $1589 \pm 355$ & $1638 \pm 478$ & $2064 \pm 640$ & 2439 \\
\hline V & $57 \pm 10$ & $74 \pm 1$ & $65 \pm 6$ & 55 \\
\hline $\mathrm{Cr}$ & $145 \pm 61$ & $682 \pm 782$ & $131 \pm 40$ & 117 \\
\hline $\mathrm{Mn}$ & $371 \pm 93$ & $626 \pm 279$ & $485 \pm 261$ & 567 \\
\hline Co & $12 \pm 3$ & $45 \pm 27$ & $12 \pm 2$ & 10 \\
\hline $\mathrm{Ni}$ & $209 \pm 135$ & $324 \pm 200$ & $164 \pm 64$ & 54 \\
\hline $\mathrm{Cu}$ & $770 \pm 266$ & $301 \pm 4$ & $702 \pm 272$ & 401 \\
\hline $\mathrm{Zn}$ & $1313 \pm 326$ & $1292 \pm 545$ & $1141 \pm 299$ & 654 \\
\hline $\mathrm{Ga}$ & $6 \pm 2$ & $6 \pm 1$ & $8 \pm 2$ & 10 \\
\hline $\mathrm{Ge}$ & $0.40 \pm 0.61$ & $<\mathrm{LD}$ & $0.68 \pm 0.67$ & 0.52 \\
\hline As & $19 \pm 9$ & $13 \pm 5$ & $15 \pm 3$ & 18 \\
\hline $\mathrm{Se}$ & $3 \pm 2$ & $6 \pm 0$ & $4 \pm 0$ & 3 \\
\hline $\mathrm{Rb}$ & $30 \pm 10$ & $28 \pm 2$ & $47 \pm 12$ & 61 \\
\hline $\mathrm{Sr}$ & $178 \pm 76$ & $203 \pm 19$ & $220 \pm 83$ & 178 \\
\hline $\mathrm{Y}$ & $10 \pm 4$ & $11 \pm 2$ & $11 \pm 5$ & 16 \\
\hline $\mathrm{Zr}$ & $152 \pm 57$ & $88 \pm 8$ & $167 \pm 23$ & 160 \\
\hline $\mathrm{Nb}$ & $12 \pm 3$ & $30 \pm 24$ & $17 \pm 5$ & 23 \\
\hline Mo & $46 \pm 75$ & $56 \pm 8$ & $62 \pm 5$ & 28 \\
\hline $\mathrm{Cd}$ & $1.0 \pm 0.4$ & $6.8 \pm 3.5$ & $0.7 \pm 0.1$ & 0.5 \\
\hline Sn & $107 \pm 28$ & $25 \pm 15$ & $115 \pm 58$ & 81 \\
\hline $\mathrm{Sb}$ & $54 \pm 18$ & $15 \pm 7$ & $59 \pm 32$ & 40 \\
\hline Cs & $1 \pm 1$ & $2 \pm 0$ & $4 \pm 1$ & 5 \\
\hline $\mathrm{Ba}$ & $755 \pm 276$ & $387 \pm 194$ & $931 \pm 279$ & 533 \\
\hline $\mathrm{La}$ & $11 \pm 4$ & $15 \pm 2$ & $15 \pm 6$ & 25 \\
\hline $\mathrm{Ce}$ & $23 \pm 9$ & $22 \pm 3$ & $32 \pm 14$ & 53 \\
\hline $\mathrm{Hf}$ & $5 \pm 1$ & $2 \pm 0$ & $5 \pm 1$ & 4 \\
\hline W & $9 \pm 19$ & $5 \pm 7$ & $3 \pm 3$ & 6 \\
\hline $\mathrm{Tl}$ & $0.00 \pm 0.00$ & $0.31 \pm 0.44$ & $0.00 \pm 0.00$ & 0.00 \\
\hline $\mathrm{Pb}$ & $117 \pm 17$ & $194 \pm 4$ & $149 \pm 34$ & 126 \\
\hline $\mathrm{Bi}$ & $4 \pm 2$ & $2 \pm 0$ & $6 \pm 4$ & 3 \\
\hline Th & $5 \pm 2$ & $4 \pm 0$ & $7 \pm 3$ & 10 \\
\hline $\mathrm{U}$ & $4 \pm 2$ & $2 \pm 1$ & $4 \pm 0$ & 3 \\
\hline
\end{tabular}

- $\mathrm{PM}_{10}$ and $\mathrm{PM}_{2.5}$ analyses at Granada Norte (traffic site in Granada). A total of 217 PM samples were used (183 $\mathrm{PM}_{10}$ and $34 \mathrm{PM}_{2.5}$ samples) against 31 components of PM.

- $\mathrm{PM}_{10}$ and $\mathrm{PM}_{2.5}$ analyses at Carranque (traffic) (Málaga). A total of 222 PM samples were used (175 
Table 3. Average absolute $\left(\mu \mathrm{g} \mathrm{m}^{-3}\right)$ and relative (\%) source contributions to $\mathrm{PM}_{10}$ and $\mathrm{PM}_{2.5}$ levels.

\begin{tabular}{|c|c|c|c|c|c|c|c|c|c|c|c|c|c|c|}
\hline \multirow[t]{2}{*}{ PM size } & \multirow[t]{2}{*}{ Province } & \multirow[t]{2}{*}{ Monitoring site } & \multirow[t]{2}{*}{ Type of site } & \multirow[t]{2}{*}{$\mathrm{PM}\left(\mu \mathrm{g} \mathrm{m}^{-3}\right)$} & \multicolumn{10}{|c|}{ Sources } \\
\hline & & & & & Mineral & $\begin{array}{r}\text { Secondary } \\
\text { nitrate }\end{array}$ & $\begin{array}{r}\text { Heavy } \\
\text { oil }\end{array}$ & $\begin{array}{l}\text { Vehicle } \\
\text { exhaust }\end{array}$ & Metallurgy & $\begin{array}{r}\text { Secondary } \\
\text { sulphate }\end{array}$ & $\begin{array}{l}\text { Sea } \\
\text { salt }\end{array}$ & $\begin{array}{r}\text { Road } \\
\text { dust }\end{array}$ & $\begin{array}{l}\text { Tyre } \\
\text { wear }\end{array}$ & $\begin{array}{r}\text { Traffic/ } \\
\text { secondary }\end{array}$ \\
\hline $\mathrm{PM}_{10}$ & Seville & Príncipes & Traffic & 41 & $\begin{array}{r}6.7 \\
(16 \%)\end{array}$ & $\begin{array}{r}2.0 \\
(5 \%)\end{array}$ & $(20 \%)$ & 8.1 & $(12 \%)$ & $\begin{array}{r}4.9 \\
(9 \%)\end{array}$ & $\begin{array}{r}3.6 \\
(35 \%)\end{array}$ & 14.4 & & \\
\hline $\mathrm{PM}_{10}$ & Granada & Granada Norte & Traffic & 44 & $\begin{array}{r}4.9 \\
(11 \%)\end{array}$ & & & $\begin{array}{r}8.8 \\
(20 \%)\end{array}$ & & $\begin{array}{r}3.9 \\
(9 \%)\end{array}$ & & $\begin{array}{r}10.4 \\
(24 \%)\end{array}$ & $\begin{array}{r}3.4 \\
(8 \%)\end{array}$ & $\begin{array}{r}10.9 \\
(25 \%)\end{array}$ \\
\hline $\mathrm{PM}_{10}$ & Málaga & Carranque & Traffic & 43 & $\begin{array}{r}10.6 \\
(25 \%)\end{array}$ & & $\begin{array}{r}3.0 \\
(7 \%)\end{array}$ & $\begin{array}{r}8.0 \\
(19 \%)\end{array}$ & & $\begin{array}{r}4.1 \\
(10 \%)\end{array}$ & $\begin{array}{r}6.9 \\
(16 \%)\end{array}$ & $\begin{array}{r}9.0 \\
(21 \%)\end{array}$ & & \\
\hline $\mathrm{PM}_{10}$ & Seville & Alcalá & Urban & 41 & $\begin{array}{r}6.1 \\
(15 \%)\end{array}$ & $\begin{array}{r}2.5 \\
(6 \%)\end{array}$ & & $\begin{array}{r}4.7 \\
(12 \%)\end{array}$ & & $\begin{array}{r}5.0 \\
(12 \%)\end{array}$ & $\begin{array}{r}4.1 \\
(10 \%)\end{array}$ & $\begin{array}{r}13.9 \\
(34 \%)\end{array}$ & & \\
\hline $\mathrm{PM}_{10}$ & Córdoba & Lepanto & Urban & 36 & $\begin{array}{r}6.0 \\
(17 \%)\end{array}$ & & & $\begin{array}{r}5.6 \\
(16 \%)\end{array}$ & $\begin{array}{r}3.9 \\
(11 \%)\end{array}$ & $\begin{array}{r}3.9 \\
(11 \%)\end{array}$ & $\begin{array}{r}4.6 \\
(13 \%)\end{array}$ & $\begin{array}{r}10.4 \\
(29 \%)\end{array}$ & & \\
\hline $\mathrm{PM}_{10}$ & Cádiz & Algeciras & Urban industrial & 38 & $\begin{array}{r}5.2 \\
(14 \%)\end{array}$ & $\begin{array}{r}3.1 \\
(8 \%)\end{array}$ & $\begin{array}{r}2.1 \\
(5 \%)\end{array}$ & $\begin{array}{r}6.2 \\
(16 \%)\end{array}$ & $\begin{array}{r}0.2 \\
(<1 \%)\end{array}$ & $\begin{array}{r}7.5 \\
(20 \%)\end{array}$ & $\begin{array}{r}4.6 \\
(12 \%)\end{array}$ & $\begin{array}{r}6.6 \\
(17 \%)\end{array}$ & & \\
\hline $\mathrm{PM}_{10}$ & Cádiz & Los Barrios & Urban industrial & 30 & $\begin{array}{r}6.6 \\
(22 \%)\end{array}$ & $\begin{array}{r}4.7 \\
(16 \%)\end{array}$ & $\begin{array}{r}1.5 \\
(5 \%)\end{array}$ & $\begin{array}{r}2.9 \\
(10 \%)\end{array}$ & $\begin{array}{r}0.3 \\
(1 \%)\end{array}$ & $\begin{array}{r}4.5 \\
(15 \%)\end{array}$ & $\begin{array}{r}3.3 \\
(11 \%)\end{array}$ & $\begin{array}{r}5.5 \\
(18 \%)\end{array}$ & & \\
\hline $\mathrm{PM}_{10}$ & Cádiz & La Línea & Urban industrial & 37 & $\begin{array}{r}6.8 \\
(19 \%)\end{array}$ & $\begin{array}{r}4.7 \\
(13 \%)\end{array}$ & $\begin{array}{r}2.2 \\
(6 \%)\end{array}$ & $\begin{array}{r}4.9 \\
(13 \%)\end{array}$ & $\begin{array}{r}0.6 \\
(2 \%)\end{array}$ & $\begin{array}{r}5.8 \\
(16 \%)\end{array}$ & $\begin{array}{r}6.2 \\
(17 \%)\end{array}$ & $\begin{array}{r}6.3 \\
(17 \%)\end{array}$ & & \\
\hline $\mathrm{PM}_{10}$ & Cádiz & Puente Mayorga & Urban industrial & 39 & $\begin{array}{r}8.7 \\
(22 \%)\end{array}$ & $\begin{array}{r}4.9 \\
(13 \%)\end{array}$ & $\begin{array}{r}2.4 \\
(6 \%)\end{array}$ & $\begin{array}{r}3.7 \\
(10 \%)\end{array}$ & $\begin{array}{r}0.5 \\
(1 \%)\end{array}$ & $\begin{array}{r}4.7 \\
(12 \%)\end{array}$ & $\begin{array}{r}4.5 \\
(12 \%)\end{array}$ & $\begin{array}{r}8.4 \\
(22 \%)\end{array}$ & & \\
\hline $\mathrm{PM}_{10}$ & Málaga & Campillo & Rural & 15 & $\begin{array}{r}2.6 \\
(17 \%)\end{array}$ & & $\begin{array}{r}2.9 \\
(19 \%)\end{array}$ & $\begin{array}{r}3.5 \\
(23 \%)\end{array}$ & & $\begin{array}{r}2.3 \\
(15 \%)\end{array}$ & $\begin{array}{r}1.3 \\
(8 \%)\end{array}$ & $\begin{array}{r}1.3 \\
(9 \%)\end{array}$ & & \\
\hline $\mathrm{PM}_{10}$ & Córdoba & Poblado & Rural & 18 & $\begin{array}{r}6.6 \\
(37 \%)\end{array}$ & & & $\begin{array}{r}0.7 \\
(4 \%)\end{array}$ & $\begin{array}{r}0.5 \\
(3 \%)\end{array}$ & $\begin{array}{r}1.0 \\
(6 \%)\end{array}$ & $\begin{array}{r}0.7 \\
(4 \%)\end{array}$ & $\begin{array}{r}3.9 \\
(22 \%)\end{array}$ & & \\
\hline $\mathrm{PM}_{2.5}$ & Seville & Príncipes & Traffic & 31 & $\begin{array}{r}3.7 \\
(12 \%)\end{array}$ & $\begin{array}{r}1.1 \\
(4 \%)\end{array}$ & $(19 \%)$ & 5.8 & $(16 \%)$ & $\begin{array}{r}4.8 \\
(5 \%)\end{array}$ & $\begin{array}{r}1.5 \\
(31 \%)\end{array}$ & 9.5 & & \\
\hline $\mathrm{PM}_{2.5}$ & Granada & Granada Norte & Traffic & 37 & $\begin{array}{r}2.3 \\
(6 \%)\end{array}$ & & & $\begin{array}{r}6.5 \\
(18 \%)\end{array}$ & & $\begin{array}{r}1.3 \\
(4 \%)\end{array}$ & & $\begin{array}{r}8.2 \\
(22 \%)\end{array}$ & $\begin{array}{r}6.6 \\
(18 \%)\end{array}$ & $\begin{array}{r}9.9 \\
(27 \%)\end{array}$ \\
\hline $\mathrm{PM}_{2.5}$ & Málaga & Carranque & Traffic & 23 & $\begin{array}{r}2.8 \\
(12 \%)\end{array}$ & & $\begin{array}{r}2.7 \\
(12 \%)\end{array}$ & $\begin{array}{r}2.8 \\
(12 \%)\end{array}$ & & $\begin{array}{r}4.1 \\
(17 \%)\end{array}$ & $\begin{array}{r}2.4 \\
(10 \%)\end{array}$ & $\begin{array}{r}4.8 \\
(21 \%)\end{array}$ & & \\
\hline $\mathrm{PM}_{2.5}$ & Seville & Alcalá & Urban & 31 & $\begin{array}{r}2.9 \\
(9 \%)\end{array}$ & $\begin{array}{r}0.9 \\
(3 \%)\end{array}$ & & $\begin{array}{r}3.2 \\
(10 \%)\end{array}$ & & $\begin{array}{r}5.4 \\
(18 \%)\end{array}$ & $\begin{array}{r}1.5 \\
(5 \%)\end{array}$ & $\begin{array}{r}9.5 \\
(31 \%)\end{array}$ & & \\
\hline $\mathrm{PM}_{2.5}$ & Córdoba & Lepanto & Urban & 18 & $\begin{array}{r}1.5 \\
(8 \%)\end{array}$ & & & $\begin{array}{r}3.8 \\
(22 \%)\end{array}$ & $\begin{array}{r}3.4 \\
(19 \%)\end{array}$ & $\begin{array}{r}3.5 \\
(20 \%)\end{array}$ & $\begin{array}{r}2.1 \\
(12 \%)\end{array}$ & $\begin{array}{r}1.9 \\
(11 \%)\end{array}$ & & \\
\hline $\mathrm{PM}_{2.5}$ & Cádiz & Algeciras & Urban industrial & 25 & $\begin{array}{r}0.9 \\
(4 \%)\end{array}$ & $\begin{array}{r}2.9 \\
(12 \%)\end{array}$ & $\begin{array}{r}2.6 \\
(11 \%)\end{array}$ & $\begin{array}{r}5.0 \\
(20 \%)\end{array}$ & $\begin{array}{r}<0.1 \\
(<1 \%)\end{array}$ & $\begin{array}{r}6.2 \\
(25 \%)\end{array}$ & $\begin{array}{r}1.5 \\
(6 \%)\end{array}$ & $\begin{array}{r}1.5 \\
(6 \%)\end{array}$ & & \\
\hline $\mathrm{PM}_{2.5}$ & Cádiz & Los Barrios & Urban industrial & 22 & $\begin{array}{r}1.6 \\
(7 \%)\end{array}$ & $\begin{array}{r}2.4 \\
(11 \%)\end{array}$ & $\begin{array}{r}2.0 \\
(9 \%)\end{array}$ & $\begin{array}{r}2.3 \\
(10 \%)\end{array}$ & $\begin{array}{r}0.1 \\
(<1 \%)\end{array}$ & $\begin{array}{r}5.6 \\
(25 \%)\end{array}$ & $\begin{array}{r}2.6 \\
(12 \%)\end{array}$ & $\begin{array}{r}3.6 \\
(16 \%)\end{array}$ & & \\
\hline $\mathrm{PM}_{2.5}$ & Cádiz & La Línea & Urban industrial & 20 & $\begin{array}{r}1.1 \\
(5 \%)\end{array}$ & $\begin{array}{r}2.3 \\
(11 \%)\end{array}$ & $\begin{array}{r}2.7 \\
(13 \%)\end{array}$ & $\begin{array}{r}3.5 \\
(17 \%)\end{array}$ & $\begin{array}{r}0.1 \\
(1 \%)\end{array}$ & $\begin{array}{r}6.9 \\
(34 \%)\end{array}$ & $\begin{array}{r}1.9 \\
(9 \%)\end{array}$ & $\begin{array}{r}1.7 \\
(8 \%)\end{array}$ & & \\
\hline $\mathrm{PM}_{2.5}$ & Málaga & Campillo & Rural & 19 & $\begin{array}{r}2.4 \\
(12 \%)\end{array}$ & & $\begin{array}{r}3.9 \\
(20 \%)\end{array}$ & $\begin{array}{r}3.9 \\
(20 \%)\end{array}$ & & $\begin{array}{r}2.7 \\
(14 \%)\end{array}$ & $\begin{array}{r}4.7 \\
(24 \%)\end{array}$ & $\begin{array}{r}1.4 \\
(7 \%)\end{array}$ & & \\
\hline
\end{tabular}

$\mathrm{PM}_{10}$ and $47 \mathrm{PM}_{2.5}$ samples) against 29 components of PM.

- $\mathrm{PM}_{10}$ and $\mathrm{PM}_{2.5}$ analyses at Campillo (rural site in the province of Málaga). A total of 95 PM samples were used (54 $\mathrm{PM}_{10}$ and $41 \mathrm{PM}_{2.5}$ samples) against $26 \mathrm{com}$ ponents of PM.

For each PMF analysis, the selection of species was based on the twofold criterion of $\mathrm{S} / \mathrm{N}$ (signal to noise) ratio and \% of data above detection limit (Amato et al., 2009b). Details are shown in Table S2 in the Supplement.

Moreover, temporal trends of source contributions were analyzed at those monitoring sites where at least four years of data were available. The Theil-Sen method (Theil, 1950; Sen, 1968), available in the Openair software (Carslaw, 2012; Carslaw and Ropkins, 2012), was applied to the monthly averages to calculate the regression parameters of the trends including slope, uncertainty in the slope and the $p$ value. The applied method yields accurate confidence intervals even with non-normal data and it is less sensitive to outliers and missing values (Hollander and Wolfe, 1999). Data were deseasonalized and all the regression parameters were estimated through bootstrap resampling. The slopes indicate how road dust contributions have changed through time and are expressed in units $\left(\mu \mathrm{g} \mathrm{m}^{-3}\right)$ per year. The $p$ values show whether the calculated trends are statistically significant. A statistically significant trend was assumed at the 90th percentile significance level $(p<0.1$ or + ), meaning that there was a $90 \%$ chance that the slope was not due to random chance. $p$ values $>0.1$ indicate insignificant trends, whilst $p$ values $=0.01$ and 0.001 (marked by $* *$ and $* * *$ ) indicate high and very high significant trends, respectively.

\section{Results and discussion}

\subsection{Road dust composition and sources}

As mentioned previously, the chemical composition of road dust at each city was investigated with two main objectives:

- identifying the main sources of road dust and estimating their contribution to road dust loadings $\left(\mathrm{mg} \mathrm{m}^{-2}\right)$ measured on active traffic lanes (this Sect.);

- estimating the contribution of road dust to the levels of ambient $\mathrm{PM}_{10}$ and $\mathrm{PM}_{2.5}\left(\mu \mathrm{g} \mathrm{m}^{-3}\right)$ measured at the PM monitoring sites under study (Sect. 3.2). 
Road dust loadings have already been discussed in Amato et al. (2013). Briefly, typical urban roads showed emission factors within $77-480 \mathrm{mg} \mathrm{veh}^{-1} \mathrm{~km}^{-1}$; the averages were $158 \pm 90 \mathrm{mg} \mathrm{veh}^{-1} \mathrm{~km}^{-1}$ in Córdoba, $\quad 180 \pm 113 \mathrm{mg} \mathrm{veh}^{-1} \mathrm{~km}^{-1} \quad$ in Málaga, $\quad 189 \pm 27 \mathrm{mg} \mathrm{veh}^{-1} \mathrm{~km}^{-1}$ in Seville and $347 \pm 144 \mathrm{mg} \mathrm{veh}^{-1} \mathrm{~km}^{-1}$ in Granada. These values are at the upper edge of the range observed in Europe and the US. An increasing trend of emission factors was observed from freeway to urban to urban-construction and, finally, to industrial sites. After averaging the elemental concentrations at the four roads under study in each city, results show that the main components of respirable $(<10 \mu \mathrm{m})$ road dust particles are $\mathrm{OC}, \mathrm{Ca}, \mathrm{EC}, \mathrm{Al}_{2} \mathrm{O}_{3}, \mathrm{Fe}$ and $\mathrm{Mg}$ (silica was not analyzed) (Fig. 2). Concerning trace elements strong enrichments in $\mathrm{Ti}, \mathrm{Zn}, \mathrm{Cu}, \mathrm{Ba}, \mathrm{Mn}, \mathrm{Sn}, \mathrm{Sb}, \mathrm{Zr}$ and $\mathrm{Sr}$ were found (Fig. 2). The relative proportion of these components may vary depending on the importance of the different sources involved: road wear, tire wear, brake wear, other minerals (unpaved areas, works) and motor exhaust. This results in a varying composition depending on the type of road (Table 2):

- typically urban roads showed higher relative concentrations of $\mathrm{OC}, \mathrm{EC}, \mathrm{Cu}, \mathrm{Ba}, \mathrm{Sn}, \mathrm{Sb}, \mathrm{Bi}$ and $\mathrm{W}$ (usually produced by abrasion of brakes, road and tires) and $\mathrm{Cl}^{-}$. Interestingly, a correlation was found between the loadings of $\mathrm{Fe}-\mathrm{Cu}-\mathrm{Zn}\left(\mathrm{mg} \mathrm{m}^{-2}\right)$ and the distance between sampling point and braking areas such as traffic lights and roundabouts (Fig. S1 in the Supplement), regardless of roads category. This suggests that emissions of brake particles (both the airborne and deposited fraction) vary spatially within a city environment. This information is important for urban-scale modeling and exposure studies.

- industrial roads were enriched in $\mathrm{Cr}, \mathrm{Co}, \mathrm{Ni}, \mathrm{Pb}$, $\mathrm{Mn}$ and $\mathrm{Cd}$ (linked to PM deposition from stationary sources) and $\mathrm{Ca}$ (likely due to higher wear rate of road pavement by heavy duty vehicles).

- roads nearby works were enriched in $\mathrm{Ca}$, $\mathrm{Ti}$ and $\mathrm{Mg}$ (due to the handling of constructing materials and hearths movements).

- poor state of the pavement shows enrichment in Al, Ti, $\mathrm{Rb}$ and $\mathrm{K}$, typical tracers of phyllosilicates.

The PMF identified three main sources responsible for the production and build-up of respirable road dust particles on road pavement: (i) a carbonaceous source, mainly related to tire wear, although a contribution of motor exhaust and brake wear may be present; (ii) road wear, which, in specific samples (Fig. 3), includes mineral dust from unpaved areas and works; (iii) brake wear; factor profiles are shown in Fig. S2 in the Supplement. The sum of these three sources explains in average $96 \%$ of the observed road dust mass loadings;
- the carbonaceous source is composed mainly of OC and, in a minor proportion, of $\mathrm{EC}$ and $\mathrm{Ca}$, suggesting the presence of tire particles possibly attached to particles of calcite and bitumen from pavement. In average this is the main source of road dust particles (50\%). The highest contributions of this source were found in the Algeciras Bay area and in Granada. The typical urban contribution can be estimated in 3-4 $\mathrm{mg} \mathrm{m}^{-2}$ (Fig. 3).

- the road wear factor is responsible for the production of the mineral particles deposited on pavement, even though a contribution from unpaved areas and urban works cannot be discarded. The chemical profile is traced by typically crustal species such as $\mathrm{Al}, \mathrm{Ca}, \mathrm{K}$, $\mathrm{Ti}, \mathrm{Fe}$ and $\mathrm{Mg}$, but this source is also responsible for a large variance of $\mathrm{Pb}$ and $\mathrm{Hg}$. In typical urban roads, without nearby works, the contribution varies within $0.3-5.8 \mathrm{mg} \mathrm{m}^{-2}$ with an average of $1.9 \mathrm{mg} \mathrm{m}^{-2}(20 \%$, Fig. 3). In roads with nearby works and/or unpaved areas or with a poor state of the pavement, the contribution can reach up to $10 \mathrm{mg} \mathrm{m}^{-2}$ (Fig. 3).

- the brake wear factor is clearly identified as responsible for the high content in Fe (brake pads contain 13$45 \%$ of metallic iron, Amato et al., 2012), Al and Ca. Aluminum is used as abrasive in pads (as metallic Al or corundum), while calcium is used in form of calcite as a filler. This factor is also responsible for most of the variance of $\mathrm{Cu}, \mathrm{Sn}, \mathrm{Sb}, \mathrm{Cr}$ and $\mathrm{Ba}$. All these elements are used in brake pad manufacture as lubricants ( $\mathrm{Sn}$ and $\mathrm{Sb}$ sulphides), fillers (barite) and friction materials (metallic $\mathrm{Cu}, \mathrm{CuO}$ and $\mathrm{Cr}_{2} \mathrm{O}_{3}$ ). On average, Brake wear contributes $12 \%$ of road dust particles, varying within $0.2-3.0 \mathrm{mg} \mathrm{m}^{-2}$ (Fig. 3). Compared to previous studies, the percentage of road wear/mineral contribution is generally similar to that in other Spanish cities, such as Barcelona and Girona, while carbonaceous materials are higher. Central European cities, such as Zurich and Utrecht, showed much lower contributions from mineral matter (Amato et al., 2011 and 2013b).

\subsection{PM source apportionment}

For each PMF analysis the distribution of residuals, G-space plots, $F$ peak values and $Q$ values were explored for solutions with the number of factors varying between 3 and 10 . The most reliable solution identified six sources at all sites, with the exception of the Algeciras Bay area where eight sources were found (Fig. S3 in the Supplement and Table 3). Four sources were common at all sites, namely road dust (RD), mineral (MI), vehicle exhaust (VE) and secondary sulfate (SS). Sea salt (SE) was found at all sites with the exception of the traffic station in Granada. Secondary nitrate (SN), metallurgy (ME) and heavy oil (HO) were identified at six 


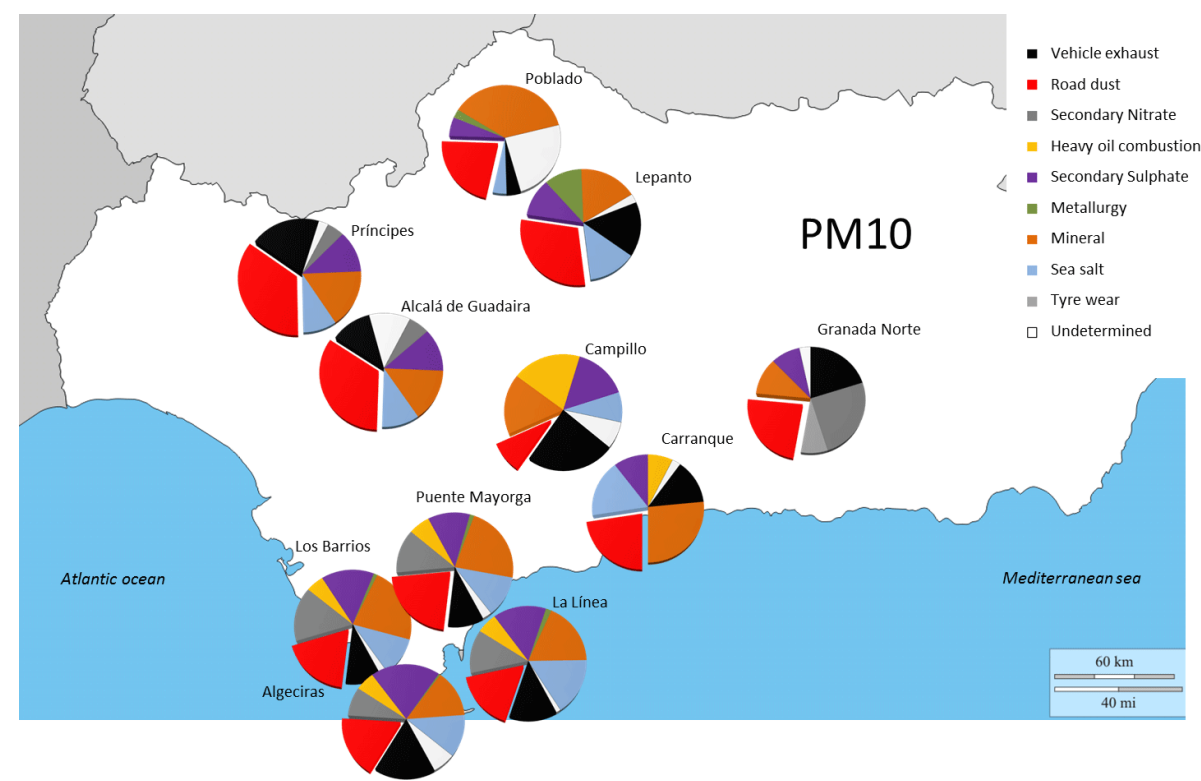

Fig. 4. Pie chart of average source contributions to $\mathrm{PM}_{10}$ levels observed at the 11 stations in Andalusia.

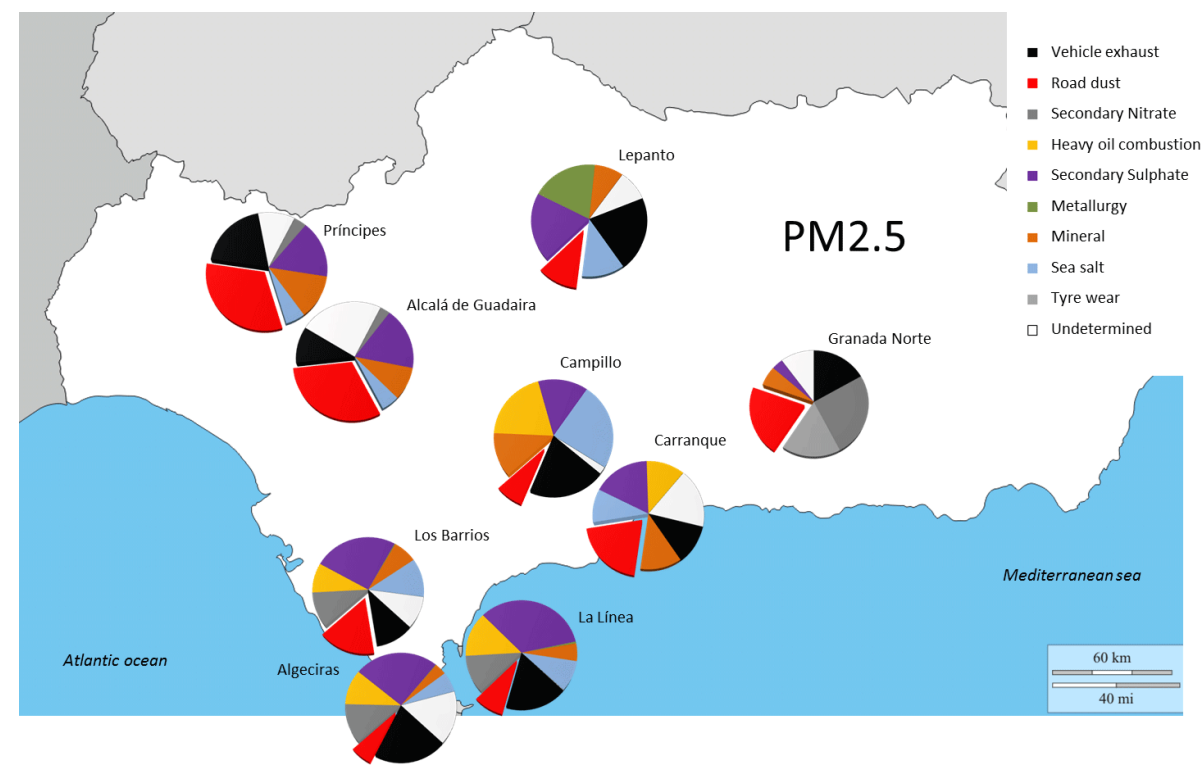

Fig. 5. Pie chart of average source contributions to $\mathrm{PM}_{2.5}$ levels observed at the 9 stations in Andalusia.

of the eleven sites (Fig. S3 in the Supplement and Table 3). Tire wear (TW) contributions could be separated only at the traffic site of Granada Norte, where also a traffic/secondary (TS) factor, linked to atmospheric stagnation conditions, was found (Fig. S3 in the Supplement and Table 3).

The yearly average road dust contribution was found to increase from rural (9-22\%) to urban-industrial (17-22\%) to urban (29-34\%) and, finally, to traffic (21-35\%) $\mathrm{PM}_{10}$ levels (Fig. 4 and Table 3). It is noteworthy that urban background stations were heavily affected by road traffic emissions. Concerning $\mathrm{PM}_{2.5}$, road dust contributions were lower but the same pattern is shown: $7 \%, 6-16 \%, 11-31 \%$ and $21-31 \%$, respectively (Fig. 5 and Table 3 ). However, it must be noted that road dust contributions show a marked seasonality with a maximum in summer and a minimum in winter, likely due to the rainfall frequency (Fig. 6).

The time trend analysis shows statistically significant decreasing trends for the road dust source at two traffic sites (in Granada and Seville, with $p$ values of 0.5 and 0.01 , respectively) and at the urban background site in Córdoba ( $p$ value 0.05 ), in most cases accompanied by stronger and more significant trends also for vehicle exhaust emissions (Figs. S4 

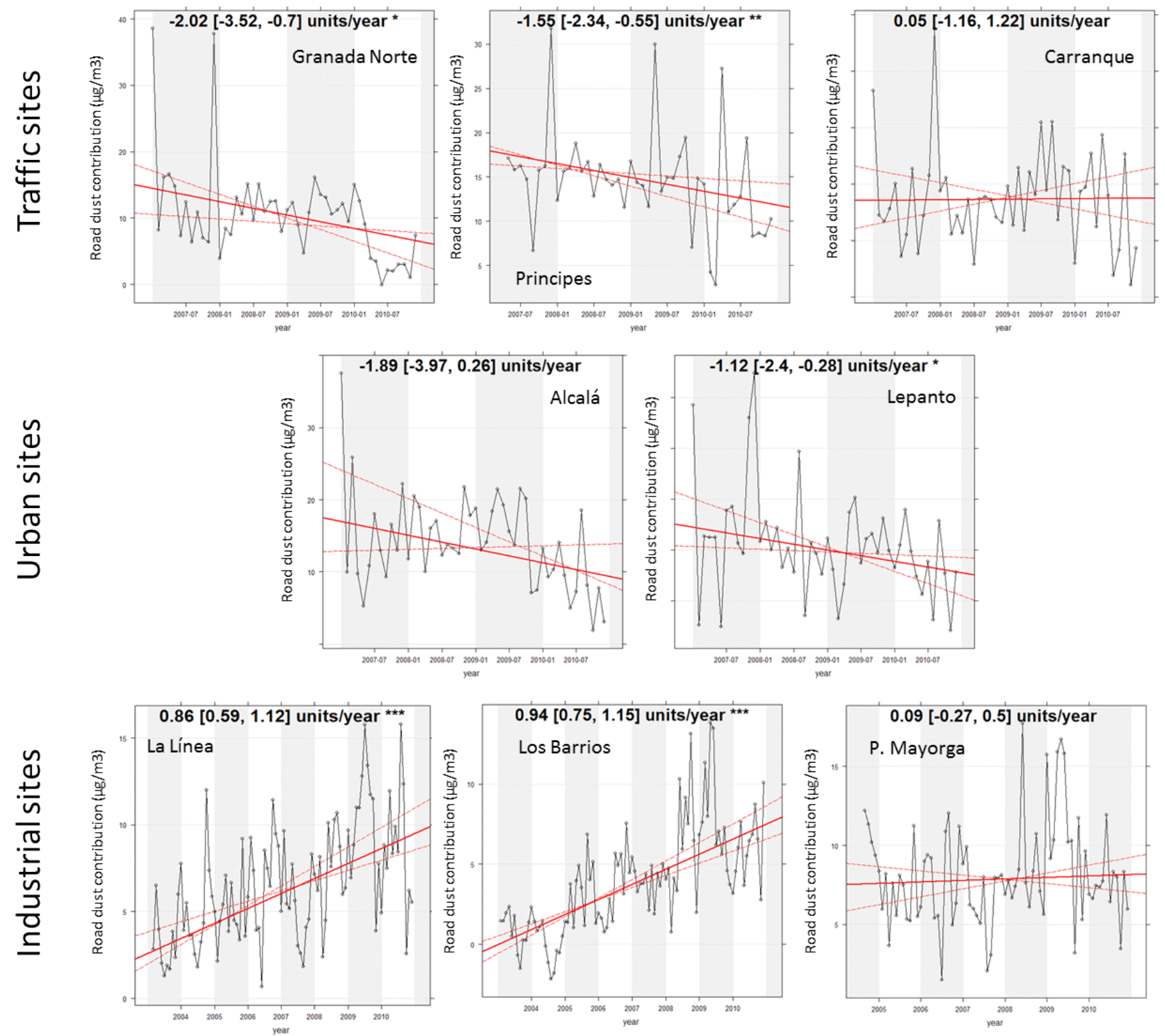

Fig. 6. Temporal trends for road dust contribution in $\mathrm{PM}_{10}$ at traffic (Granada, Seville and Málaga), urban background (Seville and Córdoba) and industrial sites (Algeciras Bay). The plots show the deseasonalized monthly mean concentrations. The solid red line shows the trend estimate and the dashed red lines show the $95 \%$ confidence intervals for the trend. The overall trend and the $95 \%$ confidence intervals in the slope (in square brackets) are shown at the top as units $\left(\mu \mathrm{g} \mathrm{m}^{-3}\right)$ per year. One, two and three asterisks indicate that the trends are significant to the $0.05,0.01$ and 0.001 levels, respectively.

and S5 in the Supplement). Overall, the downward trend of road dust contribution at the traffic sites can be estimated as $-1.5-2.0 \mu \mathrm{g} \mathrm{m}^{-3} \mathrm{yr}^{-1}$, which can be related to the decrease in construction/demolition activities from 2008 onwards, due to the financial crisis. As road dust sampling showed, particles generated by urban works significantly increase the road dust mass loadings on road surface and consequently also road dust emissions. The downward trend is in fact also found for the mineral source found at Granada Norte, Príncipes, Lepanto, Carranque, Los Barrios and La Línea.

No trend was observed at the traffic site in Málaga and at the urban background site in Seville ( $p$ value $>0.1$ ), although in Seville a clear decrease can be observed after 2009.

Increasing trends of road dust contributions were found at two of the three industrial sites (La Línea and Los Barrios) with very high statistical significance $(p=0.001)$. At these two sites, motor exhaust and mineral contributions 
decrease significantly, while only road dust and secondary nitrate (slightly) showed increasing trends (Figs. S4 and S5 in the Supplement). At the third site (Puente Mayorga) a positive trend is also shown but without statistical significance $(p>0.1)$. At the industrial sites, the increasing trend of road dust contributions is confirmed by the increase in $\mathrm{Cu}$ concentrations (a typical tracer for brake wear) by a rate of $4 \mathrm{ng} \mathrm{m}^{-3} \mathrm{yr}^{-1}$ ( $\left.p=0.001\right)$ and is possibly due to local peculiarities, such as the construction of a new parking lot and urbanization in the vicinity of the monitoring site and the proximity to the national border between Spain and Gibraltar.

\section{Conclusions}

In this study we estimated the daily contribution of road dust emissions to the $\mathrm{PM}_{10}$ and $\mathrm{PM}_{2.5}$ mass concentrations measured at 11 air quality monitoring station in Andalusia from 2003 to 2010 through a constrained PMF analysis. The chemical profiles of local road dust samples were used as targets within the multivariable regression. Road dust emissions were found to contribute largely to $\mathrm{PM}_{10}$ mass: yearly average contributions were 9-22\%, 17-22\%, 29-34\% and $21-35 \%$ of $\mathrm{PM}_{10}$ levels measured at rural, urban-industrial, urban and traffic sites, respectively. For $\mathrm{PM}_{2.5}$, road dust contributions were lower but the same pattern is shown: $7 \%$, $6-16 \%, 11-31 \%$ and $21-31 \%$, respectively. Road dust contributions were generally higher during the dry season. Negative trends across sampling years were found at traffic and urban sites, while positive trends at the industrial harbor area of Algeciras Bay (Strait of Gibraltar), probably due to local traffic peculiarities. Relative to vehicle exhaust, road dust contributions generally decrease at a lower rate and less significantly.

On average, $52 \%$ of the observed deposited mass loadings of road dust were attributed to a carbonaceous source (i.e., tire wear and bitumen), $35 \%$ to a road wear/mineral source, and $13 \%$ to brake wear. This information can help local authorities developing preventive measures to reduce road dust build-up.

\section{Supplementary material related to this article is available online at http://www.atmos-chem-phys.net/14/ 3533/2014/acp-14-3533-2014-supplement.pdf.}

Acknowledgements. This work was funded by the Government of Andalusia (Consejería de Agricultura, Pesca y Medio Ambiente) through the research projects 192/2011/C/00 "Seguimiento de los Planes de Calidad del Aire en Andalucía" and 289/2009/C/00 "Estudio de la contaminación atmosférica por material particulado en la Comunidad Autónoma de Andalucía". M. Pandolfi was funded by the Jae-DOC CSIC program co-funded by the European
Social Fund (ESF). Authors would like to thank the local traffic and police authorities for the logistic support.

Edited by: E. Gerasopoulos

\section{References}

Adame, J. A., Hernández-Ceballos, M. A., Bolívar, J. P., and De la Morena, B.: Assessment of an air pollution event in the southwestern Iberian Peninsula, Atmos. Environ., 55, 245-256, 2012.

Amato, F. and Hopke, P. K.: Source apportionment of the ambient $\mathrm{PM}_{2.5}$ across St. Louis using constrained positive matrix factorization, Atmos. Environ., 46, 329-337, 2012.

Amato, F., Pandolfi, M., Viana, M., Querol, X., Alastuey, A., and Moreno, T.: Spatial and chemical patterns of $\mathrm{PM}_{10}$ in road dust deposited in urban environment, Atmos. Environ., 43, 16501659, 2009a.

Amato, F., Pandolfi, M., Escrig, A., Querol, X., Alastuey, A., Pey, J., Perez, N., and Hopke, P. K.: Quantifying road dust resuspension in urban environment by Multilinear Engine: A comparison with PMF2, Atmos. Environ., 43, 2770-2780, 2009 b.

Amato, F., Pandolfi, M., Moreno, T., Furger, M., Pey, J., Alastuey, A., Bukowiecki, N., Prevot, A. S. H., Baltensperger, U., and Querol, X.: Sources and variability of inhalable road dust particles in three European cities, Atmos. Environ., 45, 6777-6787, 2011.

Amato, F., Pandolfi, M., Alastuey, A., Lozano, A., Contreras González, J., and Querol, X.: Impact of traffic intensity and pavement aggregate size on road dust particles loading, Atmos. Environ., 77, 711-717, 2013a.

Amato, F., Schaap, M., Denier van der Gon, H. A. C., Pandolfi, M., Alastuey, A., Keuken, M., and Querol, X.: Short-term variability of mineral dust, metals and carbon emission from road dust resuspension, Atmos. Environ., 74, 134-140, 2013b.

Birch, M. E. and Cary, R. A.: Elemental carbon-based method for monitoring occupational exposures to particulate diesel exhaust, Aerosol Sci. Tech., 25, 221-241, 1996.

Cahill, T. A., Barnes, D. E., Spada, N. J., Lawton, J. A., and Cahill, T. M.: Very fine and ultrafine metals and ischemic heart disease in the California central valley 1: 2003-2007, Aerosol Sci. Tech., 45, 1123-1134, 2011.

Carslaw, D. C.: The openair manual - open-source tools for analysing air pollution data, Manual for version 0.7-0, King's College, London, 2012.

Carslaw, D. C. and Ropkins, K.: Openair - an R package for air quality data analysis, Environ. Modell. Softw., 27-28, 52-61, 2012.

Cavalli, F., Viana, M., Yttri, K. E., Genberg, J., and Putaud, J.-P.: Toward a standardised thermal-optical protocol for measuring atmospheric organic and elemental carbon: the EUSAAR protocol, Atmos. Meas. Tech., 3, 79-89, doi:10.5194/amt-3-79-2010, 2010.

de la Rosa, J. D., Sanchez de la Campa, A. M., Alastuey, A., Querol, X., Gonzalez-Castanedo, Y., Fernandez-Camacho, R., and Stein, A. F.: Using $\mathrm{PM}_{10}$ geochemical maps for defining the origin of atmospheric pollution in Andalusia (Southern Spain), Atmos. Environ., 44, 4595-4605, 2010.

Denier van der Gon, H., Gerlofs-Nijland, M. E., Gehrig, R., Gustafsson, M., Janssen, N., Harrison, R. M., Hulskott, J., 
Johansson, C., Jozwicka, M., Keuken, M., Krijgsheld, K., Ntziachristos, L., Riediker, M., and Cassee, F. R.: The Policy Relevance of Wear Emissions from Road Transport, Now and in the Future - An International Workshop Report and Consensus Statement, J Air Waste Manage., 63, 136-49, 2013.

EEA: Air quality in Europe - 2012 Report EEA Technical Report No. 4/2012, 2012.

García Lorenzo, E., De la Rosa, J., and Sanchez de la Campa, A.: Caracterización físicoquímica y origen del material particulado atmosférico en la ciudad de Córdoba. Trabajo de investigación de Máster de Tecnología Ambiental. Universidad de Huelva, 2011.

González Castanedo, Y.: Caracterización físico-química del material particulado atmosférico de origen industrial en Andalucía. Tesis Doctoral. Universidad de Huelva, Mayo 2011.

Gustafsson, M., Blomqvist, G., Gudmundsson, A., Dahl, A., Swietlicki, E., Bohgard, M., Lindbom, J., and Ljungman, A.: Properties and toxicological effects of particles from the interaction between tyres, road pavement and winter traction material, Sci. Total Environ., 393, 226-240, 2008.

Harrison, R. H., Stedman, J., and Derwent, D.: New directions: why are $\mathrm{PM}_{10}$ concentrations in Europe not falling?, Atmospheric science perspectives special series, Atmos. Environ., 42, 603606, 2008.

Hollander, M. and Wolfe, D. A.: Nonparametric Statistical Methods, 2nd Edn., New York, John Wiley \& Sons, 421-423, 1999.

Kousoulidou, M., Ntziachristos, L., Mellios, G., and Samaras, Z.: Road-transport emission projections to 2020 in European urban environments, Atmos. Environ., 42, 7465-7475, 2008.

Lozano, A., Usero, J., Vanderlinden, E., Raez, J., Contreras, J., and Navarrete B.: Air quality monitoring network design to control nitrogen dioxide and ozone, applied in Malaga, Spain, Microchem. J., 93, 164-172, 2009.

Lyamani, H., Olmo, F. J., and Alados-Arboledas, L.: Light scattering and absorption properties of aerosol particles in the urban environment of Granada, Spain, Atmos. Environ., 42, 2630-2642, 2008.

Majumdar, D., Rajaram, B., Meshram, S., and Chalapati Rao, C. V.: PAHs in road dust: Ubiquity, fate, and summary of available data, Crit. Rev. Env. Sci. Tec., 42, 1191-1232, 2012.

Meister, K., Johansson, C., and Forsberg, B.: Estimated short-term effects of coarse particles on daily mortality in Stockholm, Sweden, Environ. Health Persp., 120, 431-436, 2012.

Notario, A., Bravo, I., Adame, J. A., Díaz-de-Mera, Y., Aranda, A., Rodríguez, A., and Rodríguez, D.: Analysis of $\mathrm{NO}, \mathrm{NO}_{2}$, $\mathrm{NO}_{\mathrm{x}}, \mathrm{O}_{3}$ and oxidant $\left(\mathrm{OX}=\mathrm{O}_{3}+\mathrm{NO}_{2}\right)$ levels measured in a metropolitan area in the southwest of Iberian Peninsula, Atmos. Res., 104-105, 217-226, 2012.

Ostro, B., Tobias, A., Querol, X., Alastuey, A., Amato, F., Pey, J., Pérez, N., and Sunyer, J.: The effects of particulate matter sources on daily mortality: A case-crossover study of Barcelona, Spain, Environ. Health Persp., 119, 1781-1787, 2011.

Paatero, P.: The Multilinear Engine - a table-driven least squares program for solving multilinear problems, including the n-way parallel factor analysis model, J. Comput. Graph. Stat., 8, 854888, 1999.
Paatero, P. and Tapper, U.: Positive matrix factorization: A nonnegative factor model with optimal utilization of error estimates of data values, Environmetrics, 5, 111-126, 1994.

Pandolfi, M., Gonzalez-Castanedo, Y., Alastuey, A., de la Rosa, J. D., Mantilla, E., de la Campa, A. S., Querol, X., Pey, J., Amato, F., and Moreno, T.: Source apportionment of $\mathrm{PM}_{10}$ and $\mathrm{PM}_{2.5}$ at multiple sites in the strait of Gibraltar by PMF: Impact of shipping emissions, Environ. Sci. Pollut. R, 18, 260-269, 2011.

Pengchai, P., Furumai, H., and Nakajima, F.: Source apportionment of polycyclic aromatic hydrocarbons in road dust in Tokyo, Polycycl. Aromat. Comp., 24, 773-789, 2004.

Querol, X., Alastuey, A., Rodríguez, S., Plana, F., Ruiz, C. R., Cots, N., Massague', G., and Puig, O.: $\mathrm{PM}_{10}$ and $\mathrm{PM}_{2.5}$ source apportionment in the Barcelona metropolitan area, Catalonia, Spain, Atmos. Environ., 35, 6407-6419, 2001.

Querol, X., Alastuey, A., Ruiz, C. R., Artiñano, B., Hansson, H. C., Harrison, R. M., Buringh, E., Ten Brink, H. M., Lutz, M., Bruckmann, P., Straehl, P., and Schneider, J.: Speciation and origin of $\mathrm{PM}_{10}$ and $\mathrm{PM}_{2.5}$ in selected European cities, Atmos. Environ., 38, 6547-6555, 2004.

Querol, X., Viana, M., Alastuey, A., Amato, F., Moreno, T., Castillo, S., Pey, J., de la Rosa, J., Sánchez de la Campa, A., Artíñano, B., Salvador, P., García Dos Santos, S., Fernández-Patier, R., Moreno-Grau, S., Negral, L., Minguillón, M. C., Monfort, E., Gil, J. I., Inza, A., Ortega, L. A., Santamaría, J. M., and Zabalza, J.: Source origin of trace elements in PM from regional background, urban and industrial sites of Spain, Atmos. Environ., 41, 7219-7231, 2007.

Schaap, M., Manders, A. M. M., Hendriks, E. C. J., Cnossen, J. M., Segers A. J. S., Denier van der Gon, H. A. C., Jozwicka, M., Sauter, F., Velders, G., Matthijsen, J., and Builtjes, P. J. H.: Regional Modelling of Particulate Matter for the Netherlands, available at: http://www.pbl.nl/en/publications/2009/ Regional-modelling-of-particulate-matter-for-the-Netherlands (last access: 7 April 2014), 2009.

Sen, P. K.: Estimates of regression coefficient based on kendall's tau, J. Am. Stat. Assoc., 63, 1379-1389, 1968.

Theil, H.: A rank invariant method of linear and polynomial regression analysis, i, ii, iii, P. K. Ned. Akad. A Math., 53, 386-392, 1950.

Viana, M., Kuhlbusch, T. A. J., Querol, X., Alastuey, A., Harrison, R. M., Hopke, P. K., Winiwarter, W., Vallius, M., Szidat, S., Prévôt, A. S. H., Hueglin, C., Bloemen, H., Wåhlin, P., Vecchi, R., Miranda, A. I., Kasper-Giebl, A., Maenhaut, W., and Hitzenberger, R.: Source apportionment of particulate matter in Europe: A review of methods and results, J. Aerosol Sci., 39, 827-849, 2008.

Yanosky, J. D., Tonne, C. C., Beevers, S. D., Wilkinson, P., and Kelly, F. J.: Modeling exposures to the oxidative potential of $\mathrm{PM}_{10}$, Environ. Sci. Technol., 46, 7612-7620, 2012. 